\title{
Effect of Broiler Breeder Age and Glutamine Supplementation on the Development of the Intestinal Mucosa of 7-Day-Old Chicks
}

Author(s)
Maiorka $A^{\prime}$
Silva AVF'
Santin $E^{\prime}$
Dahlke F'
Bruno LDG"
Boleli IC"I
Macari M"I
Trautenmuller H"
' Universidade Federal do Paraná - CEP
80035-050 Curitiba - PR - Brasil
" Universidade Estadual do Oeste do Paraná
- CCA - CEP 85960-000 - Marechal Cândi-
do Rondon - PR - Brasil
"I Faculdade de Ciências Agrárias e Veteriná-
rias - Unesp - CEP 14884-900 - Jaboticabal
- SP - Brasil

\section{-Mail Address}

Corresponding author e-mail address Alex Maiorka

Universidade Federal do Paraná/Setor de Ciências Agrárias

Departamento de Zootecnia

Rua dos Funcionários, 1540

CEP 80035-050 Curitiba PR

Phone: +55 4133505732

Fax: $\quad+554132524149$

E-mail: amaiorka@ufpr.br

\section{- Keywords}

Broiler breeder age, glutamine, intestinal mucosa, morphology.

\section{ABSTRACT}

The aim of this study was to evaluate the possible effects of glutamine and broiler breeder age on the development of intestinal mucosa in broiler chicks during first week of age. For this purpose, 32 one-day-old broiler chicks were distributed according to a completely randomized experimental design in a $2 \times 2$ factorial arrangement. Treatments consisted of two broiler breeder ages (30 and 60 weeks) and two dietary glutamine supplementation levels ( $0 \%$ and $1 \%)$. The morphological development of intestinal mucosa, particularly villus height and crypt depth, was evaluated. The results showed that the supplementation with $1 \%$ of glutamine influenced the development of villus height in the duodenum $(p=0.009)$, jejunum $(p=0.006)$, and ileum ( $p=0.001)$, as well as crypt depth in the jejunum ( $p=0.037)$ of 7-day-old broilers. These results suggest that the presence of glutamine influenced the development of intestinal mucosa during the first week of age, when these tissues are highly influenced by dietary components, especially by trophic agents. The results show that broiler breeder age (30 or 60 weeks) did not influence the evaluated parameters.

\section{INTRODUCTION}

Literature studies have demonstrated the importance of maintaining the health of the intestinal mucosa of poultry to achieve good productivity. This is especially true for broilers, which have a short lifespan. Very good intestinal health status is required because intestinal epithelium cells are responsible for nutrient absorption and for defense against pathogens (Maiorka et al., 2000).

At hatching, despite anatomically complete, the gastrointestinal tract (GIT) is still physiologically immature (Maiorka et al., 2000; Murakami et al., 2007), resulting in inefficient dietary nutrient utilization, and consequently, preventing chicks to achieve their genetic growth potential.

Some compounds are supplemented in pre-starter and starter broiler diets with the aim to stimulate the development of the intestinal mucosa. One of these substances is glutamine, which is a trophic agent. It supplies optimal enterocyte nutrition and it is known for maintaining enterocyte development rate and, in some cases, for stimulating the proliferation of enterocytes after damages of the intestinal mucosa (Rhoads et al., 1997). Well-developed and functional enterocytes are required for proper dietary nutrient absorption.

It was reported that glutamine increases gene transcription by increasing the mitogenic activity of the enzyme protein kinase (Blikslarger \& Roberts, 1997), leading to more effective synthesis or turnover of the involved tissues. However, the mechanism by which glutamine stimulates the proliferation of enterocytes is not fully elucidated. Two 
Maiorka A, Silva AVF, Santin E, Dahlke F, Bruno LDG, Boleli IC, Macari M, Trautenmuller $\mathrm{H}$

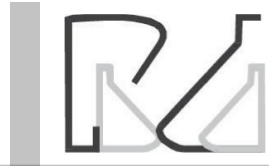

mechanisms have been proposed: glutamine may increase $\mathrm{Na}^{+} / \mathrm{H}^{+}$exchange on the cell membrane, as well as enhance the specific activity of the enzyme ornithine-decarboxylase, essential for cell proliferation (Rhoads et al., 1997Moreover, glutamine is a precursor of the synthesis of amino acids, nucleotides, and nucleic acids (Souba, 1993; Murakami et al., 2007). However, endogenous glutamine production is not sufficient to supply the body requirements (Lobley et al., 2001). Therefore, the supply of an exogenous glutamine source may be useful to promote the development of the GIT, particularly of the intestinal mucosa.

There is positive correlation between broiler breeder age and egg size and, consequently, between broiler breeder age and chick size. Chicks from young broiler breeders are lighter when compared with chicks of the same age from older broiler breeders (Dalanezi et al., 2005). This difference may be maintained during the entire broiler life. The study of Wilson (1991), for instance, showed that a difference of one gram in egg weight results in 2-13 gram differences in the body weight of 6-wk-old broilers. Eggs laid by young broiler breeders present lower yolk and albumen contents, and therefore lower nutrient levels available to the developing embryo (Noy \& Pinchasov, 1993).

Therefore, the objective of this experiment was to evaluate the effects of the dietary supplementation of glutamine during the first week after hatching on the development of the intestinal mucosa (villus height, crypt depth, number of the villi/segment, surface area of the tip of the enterocytes and length of the small intestine) of broiler chicks derived from breeders of different ages (30 and 60 weeks old).

\section{MATERIAL AND METHODS}

A total of 32 one-day-old male Cobb-500 ${ }^{\text {TM }}$ chicks (16 hatched from 30-wk-old breeders and 16 hatched from 60-wk-old breeders) were placed immediately after hatching in battery cages located an environmentally controlled chamber at thermoneutral temperature $\left(33^{\circ} \mathrm{C}\right)$. Chicks were distributed according to a completely randomized experimental design in a $2 \times 2$ factorial arrangement, consisting of two broiler breeder ages (30 and 60 weeks) and two dietary glutamine supplementation levels ( $0 \%$ and $1 \%)$, with four treatments of eight birds each. The following treatments were applied:

- T1: chicks from 30-wk-old breeders and fed a diet supplemented with $1 \%$ glutamine;

- T2: chicks from 60-wk-old breeders and fed a diet supplemented with $1 \%$ glutamine,
Effect of Broiler Breeder Age and Glutamine Supplementation on the Development of the Intestinal Mucosa of 7-Day-Old Chicks

- T3: chicks from 30-wk-old breeders and fed a diet not supplemented with glutamine;

- T4: chicks from 60-wk-old breeders and fed a diet not supplemented with glutamine.

The diets were based on corn and soybean meal. Diet composition is shown in Table 1. Glutamine was supplemented at $1 \%$ of the diet as L-glutamine. Chicks are fed ad libitum during the entire experimental period (7 days).

At the end of the experimental period or seven days after hatching, eight birds per treatment were sacrificed by cervical dislocation. The small intestine was removed for morphological evaluation and its length measured $(\mathrm{cm} \pm 0.01)$. Tissue samples (approximately $2 \mathrm{~cm}$ ) were collected from each segment of the small intestine: duodenum - from the pylorus to the distal duodenal loop; jejunum - from the distal duodenal loop to Meckel's diverticulum, and ileum - between Meckel's diverticulum and the opening of the ceca. Samples were evaluated by light microscopy, scanning electron microscopy, and transmission electron microscopy.

Table 1 - Composition of experimental diets.

\begin{tabular}{|c|c|c|}
\hline & \multicolumn{2}{|c|}{ Experimental diets } \\
\hline Ingredient & With Glutamine & Without Glutamine \\
\hline Yellow corn, \% & 51.74 & 51.74 \\
\hline Soybean meal, \% & 27.82 & 27.82 \\
\hline Corn gluten- $60, \%$ * & 9.94 & 9.94 \\
\hline Soybean oil, \% & 1.59 & 1.59 \\
\hline Dicalcium phosphate, \% & 1.71 & 1.71 \\
\hline Limestone, \% & 1.44 & 1.44 \\
\hline Vitamin supplement A, \% & 0.45 & 0.45 \\
\hline Trace mineral supplement ${ }^{\mathrm{B}}, \%$ & 0.25 & 0.25 \\
\hline Salt $(\mathrm{NaCl}), \%$ & 0.45 & 0.45 \\
\hline DL-Methionine, \% & 0.13 & 0.13 \\
\hline L-Lysine, \% & 0.12 & 0.12 \\
\hline L-Glutamine, \%** & 1.00 & 0.00 \\
\hline \multirow[t]{2}{*}{ Sand, \% } & 3.41 & 4.41 \\
\hline & \multicolumn{2}{|c|}{ Calculated analysis } \\
\hline $\mathrm{ME}, \mathrm{kcal} / \mathrm{kg}$ & 2,900 & 2,900 \\
\hline Crude protein, \% & 23.00 & 22.00 \\
\hline Calcium, \% & 1.00 & 1.00 \\
\hline Available phosphorus, \% & 0.45 & 0.45 \\
\hline Sodium, \% & 0.20 & 0.20 \\
\hline Methionine, \% & 0.51 & 0.51 \\
\hline Methionine + Cystine, \% & 0.88 & 0.88 \\
\hline Lysine $(\%)^{* * *}$ & 1.10 & 1.10 \\
\hline
\end{tabular}

A Supplied per kilogram of diet: vitamin A (11,925 IU); vitamin $D_{3}(2,250$ IU); vitamin E (9 IU); vitamin $\mathrm{K}_{3}(1.8 \mathrm{mg})$; vitamin $\mathrm{B}_{12}(0.02 \mathrm{mg})$; thiamin $(1.1 \mathrm{mg})$; riboflavin $(9 \mathrm{mg})$; pyridoxine (1.8 mg); biotin ( $0.1 \mathrm{mg})$; pantothenic acid (9,9 mg); niacin (38.25 mg); folic acid $(0.9 \mathrm{mg})$; choline $(680 \mathrm{mg})$.

${ }^{\text {B }}$ Supplied per kilogram of diet: iodine $(1.2 \mathrm{mg})$; selenium $(0.18 \mathrm{mg})$; iron $(70 \mathrm{mg})$; copper $(10 \mathrm{mg})$; zinc $(60 \mathrm{mg})$; manganese $(70 \mathrm{mg})$. 
Maiorka A, Silva AVF, Santin E, Dahlke F, Bruno LDG, Boleli IC, Macari M, Trautenmuller $\mathrm{H}$
Effect of Broiler Breeder Age and Glutamine Supplementation on the Development of the Intestinal Mucosa of 7-Day-Old Chicks

\section{Light microscopy}

Tissue samples were fixed in Bouin's solution, dehydrated in standard alcohol-toluene series (50, $60,70,80,90$, and $100 \%$ for 15 minutes each), and embedded in paraffin. Five-micrometer slices were prepared and stained with hematoxylin-eosin. Villus height $(\mu \mathrm{m})$ and crypt depth $(\mu \mathrm{m})$ were measured in 60 random microscopic fields in each segment using an image analysis system (Video Plan, Carl Zeiss, Germany).

\section{Sample preparation for electron microscopy}

The intestinal content was removed with saline solution buffered with $0.1 \mathrm{M}$ phosphate $(\mathrm{pH} 7.4)$, and tissue samples were fixed in $2 \%$ glutaraldehyde in phosphate buffer for $24 \mathrm{~h}$ at $4^{\circ} \mathrm{C}$. Subsequently, samples were washed in phosphate buffer and postfixed for two hours in 1\% osmium tetroxide. The material was washed again with the same buffer solution and dehydrated in increasing ethanol series $(50,60,70,80,90$, and $100 \%$ for 15 minutes each).

\section{Scanning electron microscopy}

Samples were dried in a critical point drier with liquid carbon dioxide. The material was then placed in an appropriate specimen tray, covered with a layer of gold (30 nm), and observed under a scanning electron microscope (model JSM 25SII ${ }^{\text {, }}$ Jeol Ltd, Japan). The average number of villi/segment was obtained by counting the number of villi in six areas measuring $103,269 \mu \mathrm{m}^{2}$ each.

\section{Transmission electron microscopy}

Segments of approximately $1 \mathrm{~mm}^{2}$ were infiltrated with 1:1 ethanol-Epon 812 resin at room temperature for 2 hours and embedded in Epon 812 resin at $60^{\circ}$ $C$ for 72 hours. The samples were then sectioned, contrasted with lead citrate and uranyl acetate and electron-microphotographed by transmission electron microscopy.

Longitudinal sections of the cells were evaluated using an image analyzer (Jeol $1010^{\circledR}$, Japan) in order to measure enterocyte diameter (tip, $\mu \mathrm{m}$ ), microvillus height and width $(\mu \mathrm{m})$, and microvillus density (microvillus number $/ 1 \mu^{2} m$ ). The average of each measurement corresponds to the measurements of 10 samples per bird.

The surface area of the tip of the enterocytes was calculated based on the tip diameter $\left(C_{d}\right)$ of the cell and the extension factor of the microvillus (EFM), according (Ferrer et al., 1995), using the equation: $S=\pi \times C_{d}^{2 / 4} \times E F M$, where $E F M=\pi \times H \times d \times D+1$ $(L=$ microvillus height; $d=$ microvillus width and $D=$ microvillus number/um²).

\section{Statistical Analysis}

Data were analyzed according to a completely randomized experimental design adopted in a $2 \times 2$ factorial arrangement (broiler breeder age $x$ glutamine supplementation) with eight replicates per treatment, using the General Linear Model procedure of SAS 8.0 software (2000).

\section{RESULTS AND DISCUSSION}

Applegate et al. (1999) reported the influence of breeder age on the intestinal development of their progeny in turkeys. Turkey poults from older breeders presented higher villi than those from younger breeder after hatch, but this difference was not maintained when poults were one week old. Accordingly, in the present study, no differences in the morphology of the intestinal mucosa of 7-d-old broilers derived from broiler breeders of different ages were detected. This suggests that the diet supplied immediately after hatch may minimize the influence of broiler breeder on the initial development of the intestinal mucosa. Applegate et al. (1999) demonstrated that animal metabolism has the ability to shown a rapid response when stimulated.

Table 2 shows the results of the supplementation of diets with $1 \%$ glutamine on the morphology of the intestinal mucosa of 7-d-old broiler chicks. The chicks fed diets with $1 \%$ glutamine presented taller longer villi in the duodenum ( $p=0.009)$, jejunum ( $p=0.006)$, and ileum ( $p=0.001$ ) compared with those fed the nonsupplemented diet. In addition, glutamine-fed chicks presented deeper crypts in the jejunum ( $p=0.037$ ), while no statistical differences were detected in the duodenum and the ileum. Table 2 also shows that broiler breeder age (30 or 60 weeks) did not influence the evaluated parameters.

Therefore, the addition of glutamine to the diet influenced villus height in the duodenum, jejunum and ileum, but not crypt depth. This suggests that the glutamine, despite being a trophic agent, did not affect the number of villi, because these originate from the bottom of the crypt.

Glutamine is known as a trophic agent that stimulates the development and proliferation of developing and regenerating tissues. Because the 
Table 2 - Villus height and crypt depth ( $\mu \mathrm{m})$ in the duodenum, jejunum and ileum of 7-d-old broiler chicks.

\begin{tabular}{|c|c|c|c|c|c|c|c|}
\hline \multirow[t]{2}{*}{ Broiler breeder age (weeks) } & \multirow{2}{*}{$\begin{array}{c}\text { Glutamine } \\
\text { supplementation }\end{array}$} & \multicolumn{2}{|c|}{ Duodenum $(\mu \mathrm{m})$} & \multicolumn{2}{|c|}{ Jejunum ( $\mu \mathrm{m})$} & \multicolumn{2}{|c|}{ Ileum $(\mu \mathrm{m})$} \\
\hline & & Villus & Crypt & Villus & Crypt & Villus & Crypt \\
\hline 30 & $(+)$ & $1131 \pm 39$ & $170 \pm 26$ & $595 \pm 70$ & $96 \pm 26$ & $505 \pm 31$ & $91 \pm 12$ \\
\hline 30 & $(-)$ & $1076 \pm 28$ & $168 \pm 34$ & $535 \pm 87$ & $85 \pm 20$ & $450 \pm 42$ & $92 \pm 13$ \\
\hline 60 & $(+)$ & $1119 \pm 57$ & $171 \pm 28$ & $598 \pm 71$ & $96 \pm 24$ & $508 \pm 30$ & $89 \pm 14$ \\
\hline \multirow[t]{2}{*}{60} & $(-)$ & $1103 \pm 71$ & $165 \pm 36$ & $531 \pm 85$ & $85 \pm 19$ & $449 \pm 36$ & $90 \pm 13$ \\
\hline & & \multicolumn{6}{|c|}{ Main effects } \\
\hline \multirow{2}{*}{ Broiler breeder age (weeks) } & 30 & 1104 & 168 & 566 & 90 & 476 & 90 \\
\hline & 60 & 1111 & 169 & 565 & 91 & 479 & 90 \\
\hline \multirow{3}{*}{ Glutamine } & $(+)$ & 1125 & 170 & 597 & 95 & 506 & 91 \\
\hline & $(-)$ & 1090 & 167 & 534 & 85 & 449 & 90 \\
\hline & & \multicolumn{6}{|c|}{ Probability } \\
\hline \multirow{3}{*}{\multicolumn{2}{|c|}{$\begin{array}{l}\text { Broiler breeder age }(A) \\
\text { Glutamine }(B) \\
\text { AxB }\end{array}$}} & 0.573 & 0.852 & 0.966 & 0.952 & 0.869 & 0.518 \\
\hline & & 0.009 & 0.644 & 0.006 & 0.037 & 0.001 & 0.892 \\
\hline & & 0.127 & 0.756 & 0.841 & 0.920 & 0.830 & 0.957 \\
\hline
\end{tabular}

gastrointestinal tract (GIT) the main absorption site of dietary nutrients required for metabolic functions, adequate GIT development is required (Maiorka, 2002), particularly during the first week of broilers' lives (Uni et al. 1998a; Maiorka, 2002), when most of the intestinal mucosa development occurs.

The effects of glutamine and broiler breeder age on microvillus height are presented on Table 3. The three segments showed different responses to the treatments. The segment where microvilli tended to be more influenced both by broiler breeder age and glutamine supplementation was the duodenum $(P=0.262$ and 0.162 , respectively), while the jejunum $(P=0.123$ and $0.793)$ and the ileum $(P=0.561$ and 0.115$)$ tended to be less affected. Because duodenal villus height was more sensitive to the action of glutamine, duodenal microvillus height was also expected to be affected.

Small intestine length and surface area of the tip of enterocytes $\left(\mu \mathrm{m}^{2}\right)$ results are shown in Table 4 . The only parameter that tended to be affected by the dietary addition of $1 \%$ glutamine was small intestine
Table 3 - Microvillus height $(\mu \mathrm{m})$ in the duodenum, jejunum, and ileum of 7-d-old broiler chicks.

\begin{tabular}{|c|c|c|c|c|}
\hline & & & licrovillus he & \\
\hline $\begin{array}{l}\text { Broiler } \\
\text { breeder age } \\
\text { (weeks) }\end{array}$ & $\begin{array}{c}\text { Glutamine } \\
\text { supplementation }\end{array}$ & $\begin{array}{l}\text { Duodenum } \\
(\mu \mathrm{m})\end{array}$ & $\begin{array}{l}\text { Jejunum } \\
(\mu \mathrm{m})\end{array}$ & Ileum ( $\mu \mathrm{m})$ \\
\hline 30 & $(+)$ & $2.41 \pm 0.61$ & $2.27 \pm 0.41$ & $2.28 \pm 0.53$ \\
\hline 30 & $(-)$ & $2.00 \pm 0.25$ & $1.96 \pm 0.19$ & $1.96 \pm 0.52$ \\
\hline 60 & $(+)$ & $2.26 \pm 0.31$ & $2.25 \pm 0.46$ & $2.12 \pm 0.37$ \\
\hline 60 & $(-)$ & $1.79 \pm 0.51$ & $2.46 \pm 0.41$ & $1.95 \pm 0.20$ \\
\hline & & & rincipal eff & \\
\hline Broiler & 30 & 2.21 & 2.12 & 2.13 \\
\hline $\begin{array}{l}\text { breeder age } \\
\text { (weeks) }\end{array}$ & 60 & 2.02 & 2.36 & 2.04 \\
\hline Glutamine & $(+)$ & 2.34 & 2.26 & 2.21 \\
\hline Gutamine & $(-)$ & 1.89 & 2.21 & 1.96 \\
\hline & & & Probabilit & \\
\hline Broiler breed & r age $(\mathrm{A})$ & 0.262 & 0.123 & 0.561 \\
\hline Glutamine (B & & 0.162 & 0.739 & 0.115 \\
\hline$A \times B$ & & 0.858 & 0.101 & 0.612 \\
\hline
\end{tabular}

length $(p=0.068)$. The surface area of the tips of the duodenum, jejunum, and ileum was not influenced by dietary glutamine supplementation or broiler breeder age.

Table 4 - Small intestinal length $(\mathrm{cm})$ and surface area of the tip of the enterocytes $(\mu \mathrm{m} 2)$ of the duodenum, jejunum, and ileum of 7-d-old broiler chicks.

\begin{tabular}{|c|c|c|c|c|c|}
\hline Broiler breeder age (weeks) & $\begin{array}{c}\text { Glutamine } \\
\text { supplementation }\end{array}$ & Intestine $(\mathrm{cm})$ & Duodenum $\left(\mu \mathrm{m}^{2}\right)$ & Jejunum $\left(\mu \mathrm{m}^{2}\right)$ & Ileum $\left(\mu m^{2}\right)$ \\
\hline 30 & $(+)$ & $77 \pm 9$ & $707 \pm 175$ & $568 \pm 91$ & $530 \pm 117$ \\
\hline 30 & $(-)$ & $71 \pm 11$ & $715 \pm 136$ & $592 \pm 101$ & $523 \pm 125$ \\
\hline 60 & $(+)$ & $74 \pm 5$ & $748 \pm 142$ & $596 \pm 137$ & $553 \pm 77$ \\
\hline 60 & $(-)$ & $73 \pm 10$ & $719 \pm 144$ & $597 \pm 85$ & $516 \pm 93$ \\
\hline & & \multicolumn{4}{|c|}{ Principal effects } \\
\hline \multirow{2}{*}{ Broiler breeder age (weeks) } & 30 & 74 & 711 & 580 & 526 \\
\hline & 60 & 74 & 733 & 596 & 534 \\
\hline \multirow{3}{*}{ Glutamine } & $(+)$ & 76 & 727 & 582 & 542 \\
\hline & $(-)$ & 72 & 717 & 594 & 519 \\
\hline & & \multicolumn{4}{|c|}{ Probability } \\
\hline \multirow{3}{*}{$\begin{array}{l}\text { Broiler breeder age }(A) \\
\text { Glutamine }(B) \\
\text { AxB }\end{array}$} & & 0.962 & 0.652 & 0.783 & 0.691 \\
\hline & & 0.068 & 0.798 & 0.836 & 0.431 \\
\hline & & 0.208 & 0.361 & 0.562 & 0.415 \\
\hline
\end{tabular}


Maiorka A, Silva AVF, Santin E, Dahlke F, Bruno LDG, Boleli IC, Macari M, Trautenmuller $\mathrm{H}$

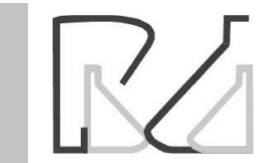

Table 5 shows the number of villi/segment determined in the duodenum, jejunum, and ileum of 7-d-old broiler chicks. The number of villi/segment (103.269 $\mu^{2}$ ) were not influenced by dietary glutamine addition or broiler breeder age.

Table 5 - Number of the villi/segment $\left(103.269 \mu \mathrm{m}^{2}\right)$, in the duodenum, jejunum and ileum on broiler chicks with 7 days of age.

\begin{tabular}{lcccc}
\hline & \multicolumn{3}{c}{ Villi/segment } \\
\hline $\begin{array}{l}\text { Broiler breeder } \\
\text { age (weeks) }\end{array}$ & Glut & Duodenum & Jejunum & Ileum \\
\hline 30 & $(+)$ & $80 \pm 12$ & $122 \pm 23$ & $190 \pm 17$ \\
30 & $(-)$ & $78 \pm 14$ & $128 \pm 25$ & $194 \pm 14$ \\
60 & $(+)$ & $77 \pm 12$ & $120 \pm 20$ & $188 \pm 8$ \\
60 & $(-)$ & $83 \pm 10$ & $123 \pm 30$ & $191 \pm 16$ \\
\hline & & \multicolumn{4}{c}{ Main effects } \\
\hline Broiler breeder & 30 & 79 & 125 & 192 \\
age (weeks) & 60 & 80 & 121 & 189 \\
\hline Glutamine & $(+)$ & 78 & 121 & 188 \\
\hline & $(-)$ & 81 & 125 & 0.596 \\
\hline Broiler breeder age (A) & & 0.533 & 0.594 & 0.470 \\
Glutamine (B) & & 0.912 & 0.511 & 0.914 \\
AxB & & 0.835 & 0.730 & \\
\hline
\end{tabular}

The results shown in Tables 3, 4, and 5 suggest that some parameters (surface of the tip of the enterocytes and number of villi/segment) presented very low susceptibility to the factors evaluated in this experiment.

Figure 1 shows some villi of the duodenum, jejunum, and ileum of broiler chickens fed diets with and without glutamine. The villi of in the evaluated segments are clearly more developed in the broilers fed glutamine compared with those fed the basal diet.

Literature reports (Lacey \& Wilmore, 1990; Murakami et al., 2007) have shown that glutamine is the most important nutrient for the development of enterocytes and has positive effects on the regeneration of intestinal mucosa after damage. Two mechanisms have been proposed for these actions: glutamine may increase $\mathrm{Na}^{+} / \mathrm{H}^{+}$exchange on the cell membrane, as well as enhance the specific activity of the enzyme ornithine-decarboxylase (Rhoads et al., 1997). That author also described an increase of gene transcription by glutamine probably due to an increase of protein kinase activity. In addition, the supplementation of broiler diets with glutamine increases the villus height in the duodenum and jejunum (Yi et al., 2005), weight gain, feed efficiency, and livability (Appeglate et al., 1999). Therefore, the supplementation of glutamine in broiler diets as early as possible enhances intestinal mucosa development.
Effect of Broiler Breeder Age and Glutamine Supplementation on the Development of the Intestinal Mucosa of 7-Day-Old Chicks

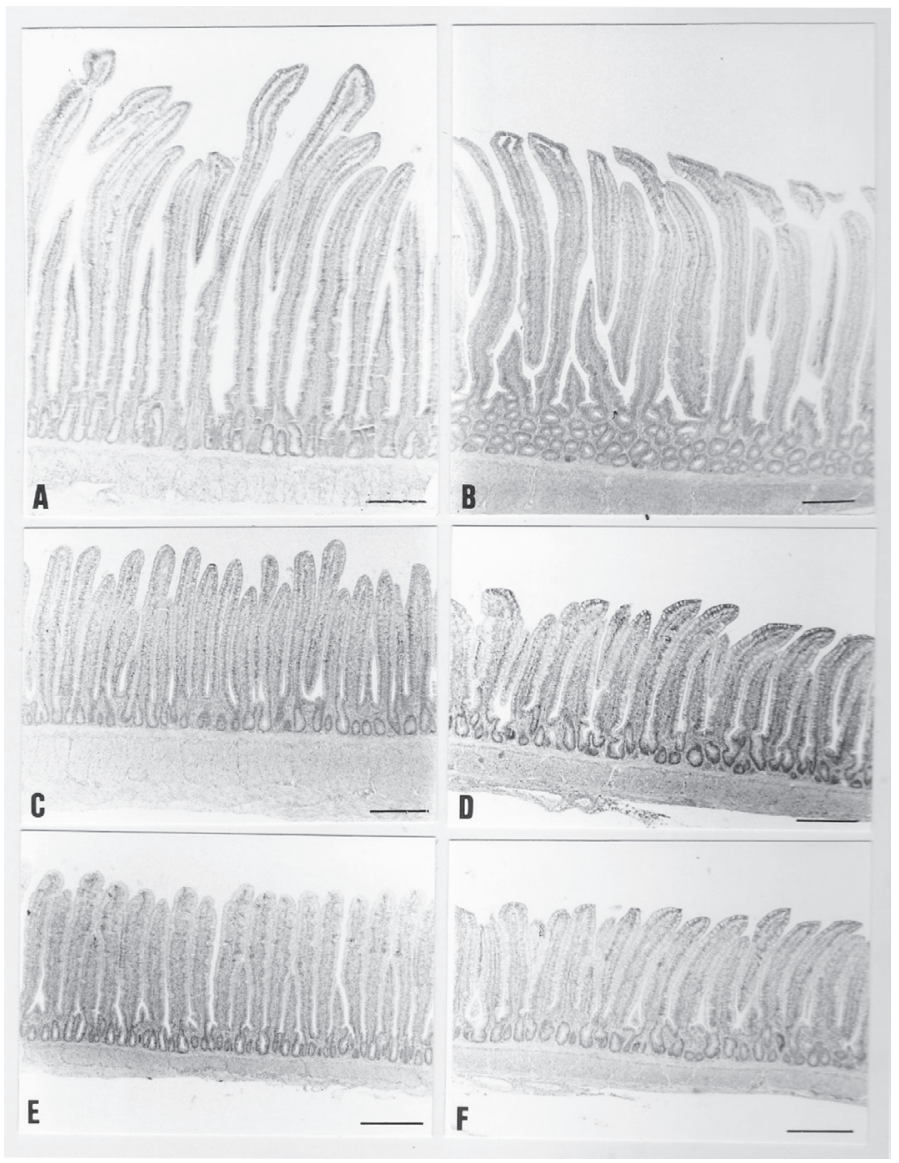

Figure 1 - Microphotographs of intestinal mucosa villi of 7-d-old broiler chicks. Duodenum of chicks fed $1 \%$ of glutamine (A) and no glutamine (B); jejunum of chicks fed $1 \%$ of glutamine (C) and no glutamine (D), ileum of chicks fed $1 \%$ of glutamine (E) and no glutamine (F).

\section{CONCLUSIONS}

The dietary supplementation of $1 \%$ glutamine influenced villus development in the intestinal mucosa of 7-day-old broiler chicks. In particular, glutamine effectively increased villus height in all segments of the small intestine and crypt depth in the jejunum. However, broiler breeder age did not influence the evaluated parameters.

\section{REFERENCES}

Applegate TJ, Dibner JJ, Kitchell ML, Uni Z, Lilburn MS. Effect of turkey (Meleagridis gallopovo) breeder hen age and egg size on poult development. 2. Intestinal villus growth, enterocyte migration and proliferation of the turkey poult. Comparative Biochemistry and Physiology 1999;124B:381-389.

Blikslarger AT, Roberts C. Mechanisms of intestinal mucosal repair. JAVMA 1997;211:1437-1441

Dalanezi JA, Mendes AA, Garcia. EA, Garcia RG, Moreira J, Paz ICLA. Efeito da idade da matriz sobre o desempenho e rendimento de carcaça de frangos de corte. Arquivos Brasileiros de Medicina Veterinária e Zootecnia 2005;57(2):250-260. 
Maiorka A, Silva AVF, Santin E, Dahlke F, Bruno LDG, Boleli IC, Macari M, Trautenmuller H
Ferrer R, Planas JM, Moretó M. Cell apical surface area in enterocytes from chicken small and large intestine during development. Poultry Science 1995;74:1995-2002

Lacey JM, Wilmore DW. Is glutamine a conditionally essential aminoacid. Nutrition Research 1990:48:297-309.

Lobley GE, Hoskin SO, McNei, CJ. Glutamine in animal science and production. Proceedings of the International Symposium of Glutamine 2001;2525S-2531S.

Maiorka A. Efeito da idade da matriz, do jejum, da energia da ração e da glutamina sobre o desenvolvimento da mucosa intestinal e atividade enzimática do pâncreas de pintos de corte [tese]. Jaboticabal (SP): Universidade Estadual Paulista; 2002.

Maiorka A, Fischer da Silva AV, Santin E, Borges AS, Boleli IC, Macari M. Influência da suplementação de glutamina sobre o desempenho e o desenvolvimento de vilos e criptas do intestino delgado de frangos. Arquivos Brasileiros de Medicina Veterinária e Zootecnia 2000;52:487490.

Maiorka A, Santin E, Fischer da Silva AV, Bruno LDG, Bolelli IC, Macari M. Influence of broiler breeder age (30 and 60 weeks) on embryonic gastrointestinal development. Brazilian Journal of Poultry Science 2000;2(2):141-148.
Effect of Broiler Breeder Age and Glutamine Supplementation on the Development of the Intestinal Mucosa of 7-Day-Old Chicks

Murakami AE, Sakamoto MI, Natali MRM, Souza LMG, Franco JRG. Supplementation of glutamine and vitamin $\mathrm{E}$ on the morphometry of the intestinal mucosa in broiler chickens. Poultry Science 2007;86:488495.

Noy $Y$, Pinchasov $Y$. Effect of a single posthatch intubation of nutrients on subsequent early performance of broiler chicks and turkey poults. Poultry Science 1993;72:1861-1866.

Rhoads JM, Argenzio RA, Chen W. L-glutamine stimulates intestinal cell proliferation and activates mitogen-activated protein kinases. American Journal of Physiology 1997;272:G943-G953.

SAS Institute. SAS $\square$ user's guide: statistics. Cary; 2000.

Souba WW. Intestinal glutamine metabolism and nutrition. The Journal of Nutritional Biochemistry 1993;4:2-9

Wilson HR. Interrelations of egg size, chick size, posthatching growth and hatchability. World's Poultry Science Journal 1991;47:5-20.

Yi GF, Allee GL, Knight CD, Dibner JJ. Impact of glutamine and oasis hatchling supplement on growth performance, small intestinal morphology, and immune response of broilers vaccinated and challenged with Eimeria máxima. Poultry Science 2005;84:283-293. 